\title{
Hydrological assessment of flash flood hazards and the constructed mitigation measures in Wadis affecting Ain Al Soukhna, Northwest Gulf of Suez, Egypt
}

\author{
Hanaa Megahed ${ }^{1}$ and Mohammed El Bastawesy ${ }^{1}$ \\ ${ }^{1}$ National Authority for Remote Sensing and Space Sciences
}

February 24, 2021

\begin{abstract}
Considerable stretches of barren coastal areas of the Gulf of Suez and the Red Sea have been covered by various anthropogenic activities during the past few decades. Several dykes have been erected on the wadi beds constituting the catchment of Wadi Ghuwaiba, which encloses the industrial zone of Ain Al Soukhna on its large alluvial fan. The multitude of optical remote sensing data, Digital Elevation Model (DEM) and thematic geological data have been integrated into Geographic Information System (GIS) to estimate the hydrological parameters of flash floods, pathways and storage capabilities of the constructed dykes upstream of the industrial zone. Due to the absence of rainfall/runoff data for these ungagged wadis, a semi-distributed hydrological model was developed using the extracted morphometric parameters from the DEM from the analyses of satellite images. Manning equation was used to compute the open channel flow velocities, and the spatial functionalities into GIS were used to estimate the cumulative flow times. Next, the catchments were subdivided into cascading time-area zones using the derivatives of flow direction, accumulation and length from the DEM. Then, the spatially distributed unit hydrograph was computed using a hypothetical rainfall distribution and runoff coefficients, and the obtained time-area zones. The dykes have been visited in the field to measure the distribution of entrapped sediment loads due to the accumulation of torrential flows in these specific areas. The magnitudes of flash floods developed from an effective rainfall of $20 \mathrm{~mm}$ will not be fully contained in the storage areas of these dykes and overflows will reach the industrial zone via uncontrolled pathways, thus the area is prone to flash flood vulnerability and additional mitigation measures are still needed. The slack deposits are accumulating with notable rates and have reached $60 \mathrm{~cm}$ in some areas. It is strongly recommended to construct a conveying channel downstream of the dykes to collect the surplus overflow and discharge it into the Gulf of Suez via a well-defined channel-pathway
\end{abstract}

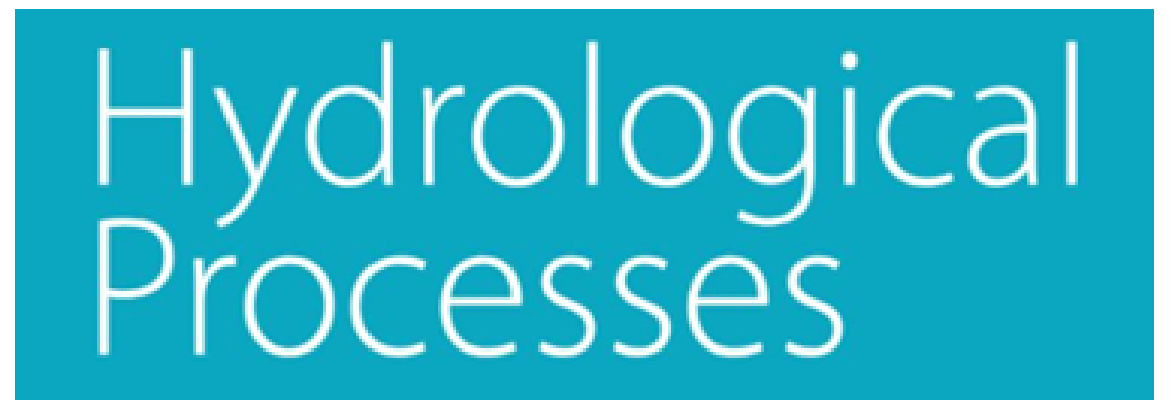

Hydrological assessment of flash flood hazards and the constructed mitigation measures in Wadis affecting Ain Al Soukhna,

Northwest Gulf of Suez, Egypt 


\begin{abstract}
Considerable stretches of barren coastal areas of the Gulf of Suez and the Red Sea have been covered by various anthropogenic activities during the past few decades, thus assessment of the interaction of natural occurring phenomena such as flash floods and the developed areas is a necessity. Several dykes have been erected on the wadi beds constituting the catchment of Wadi Ghuwaiba, which encloses the industrial zone of Ain Al Soukhna on its large alluvial fan. The multitude of optical remote sensing data, Digital Elevation Model (DEM) and thematic geological data have been integrated into Geographic Information System (GIS) to estimate the hydrological parameters of flash floods, pathways and storage capabilities of the constructed dykes upstream of the industrial zone. Due to the absence of rainfall/runoff data for these ungagged wadis, a semi-distributed hydrological model was developed using the extracted morphometric parameters from the DEM, and the reoccurrence of flash flood events and the active channels from the analyses of satellite images. Manning equation was used to compute the open channel flow velocities, and the spatial functionalities into GIS were used to estimate the cumulative flow times for each cell in the catchment. Next, the catchments were subdivided into cascading time-area zones using the derivatives of flow direction, accumulation and length from the DEM. Then, the spatially distributed unit hydrograph was computed using a hypothetical rainfall distribution and runoff coefficients, and the obtained time-area zones. The dykes have been visited in the field to measure the distribution of entrapped sediment loads due to the accumulation of torrential flows in these specific areas. The magnitudes of flash floods developed from an effective rainfall of $20 \mathrm{~mm}$ will not be fully contained in the storage areas of these dykes and overflows will reach the industrial zone via uncontrolled pathways, thus the area is prone to flash flood vulnerability and additional mitigation measures are still needed. The slack deposits are accumulating with notable rates and have reached $60 \mathrm{~cm}$ in some areas, therefore the efficiency of these dykes are also being decreased due to deposition of sediment loads associated with the flash floods. It is strongly recommended to construct a conveying channel downstream of the dykes to collect the surplus overflow and discharge it into the Gulf of Suez via a well-defined channelpathway.
\end{abstract}

KEYWORDS: Flash flood. Mitigation, Geographic Information System. Ain Al Soukhna. Egypt INTRODUCTION

The proposed sustainable development plans in the urban areas include harvesting runoff from the catchment, the recharge rate of groundwater aquifers and exploiting its resources (Megahed, 2020; Darwish et al., 2020; Farrag et al. 2019 \& Megahed and Farrag 2019). Flash flooding is one of Egypt's principal natural disasters (De Roo, 1999; Broadman et al., 1994). Due to a lack of studies and the relatively infrequent occurrence of runoff events and flooding and associated sediment transport in urban areas and archaeological sites so receive recognition as hydrological and environmental problems (Megahed, 2020; White, 1995; Gheith and Sultan, 2002). Besides, a particular problem for hydrological analyzes in dryland catchments is the lack of good quality rainfall and discharge data (Megahed and El Bastawesy, 2020; McMahon, 1979). The impact of flash floods in urban areas could vary from one catchment to another and even within the same catchment at the different events of flash floods depending on the attenuation of discharges and associated sediment loads of the flash floods (El Bastawesy et al. 2009). Geographical information system () provides several computerized techniques enabling to automatically extract the hydrological parameters from high quality digital elevation model data, such hydrological parameters include watershed and flow path delineation (Wilson and Gallant, 2000; Jenson and Domingue, 1988). Together with remotely sensed data that can provide near-real-time information on the climate, the atmosphere, the local environment and weather conditions (e.g. precipitation). At the present time, integrating both techniques could provide management of flash flood hazards (Walsh et al., 1998).

The industrial area of the northwest Gulf of Suez coastal zone is located in the southern part of a large drainage system constituted by several wadis, namely: Ghoweba, Bedaa, Hagoul, and Hamath. These wadis collect their surface runoff during occasional flash floods from a catchment area of $4300 \mathrm{~km}^{2}$ (Figure. 1). In 1999 the National Centre for Water Research has recommended the construction of several dykes on the main wadis to retain flow in their upstream to prevent flash floods from reaching the coastal area (Figure. 2). The 
locations and engineering designs for these dykes were based on amounts of flash flood runoff estimated after meteorological (rainfall), geomorphologic, geological, topographical, and field data available at the time. Due to the economic importance of the area, the maximum storage capacities for these dykes were designed to accommodate flows generated from a high magnitude storm of 50 years return period with rainfall depths ranging from 60 to $82 \mathrm{~mm}$ over the catchment. However, observed annual repeatability of significant flash floods is usually much smaller than the values considered for the selected storm design that occurs once in 50 years. Also, variable amounts of sediment loads are likely to accumulate behind these dykes and their storage capacity will decrease with time. Because the catchments were initially un-gauged with meteorological and surface runoff stations, the dyke's construction was based on a deterministic hydrological model that utilizes runoff scenarios based on arbitrarily estimated runoff coefficients mainly based on storms occurring only once each 50 years (El Bastawesy, 2005). This is the main reason for the hydrological re-assessment of the effectiveness of the erected dykes, with a particular emphasis on the dykes deserving the Wadi El Abiad sub-catchment, which may endanger the areas downstream of this wadi. The goal of the present study is to use an adequate methodology to quantify and assess potential flash flood hazards in the considered areas using remote sensing and GIS techniques with fieldwork.

\section{GEOLOGICAL SETTING AND CLIMATE}

The rock units outcropping in the considered area of the drainage basin are presented in the geological map (CONOCO, 1987) (Figure. 3). The hill slopes of Wadi El Abiad are carved in the Middle Eocene limestone of the Mokattam Formation, which caps the Northern Galala massif. This Massif is limited to the north-west by several NE/SW step faults within the steep slopes bringing the surrounding alluvial plain in abrupt contact with the Galala cliffs. Most of Wadi El Abiad main channel is confined to a deeply incised canyon running across the Galala massif. The Mokattam exposed in the Northern Galala is capped in places (mainly in down faulted blocks on the foothill of the faulted cliffs surrounding the massif) by Oligocene clastic involving chert and some limestone pebbles. By reaching the alluvial plain, Wadi El Abiad fans out forming braided alluvial channels constituting large areas. The out-washed Oligocene pebbles fill the bed of Wadi El Abiad channel and alluvial fan. The abundant coarse clastic and pebbles imply a high infiltration rate from occasional surface runoff in the drainage area. It should be noticed that the planned facility will be constructed on the westernmost distal part of the alluvial fan. This suggests that the local geological environment has a marked influence on the nature of the flash floods affecting the considered area, as the generated flows tend to decrease significantly due to the actions of channel divergence and infiltration by reaching the alluvial fan. Wadi El Abiad channel receives only less than $20 \%$ at most of the total flow delivered to the alluvial fan by any flash flood (Figure. 1). The remaining $80 \%$ or more of the flows are routed through the other channels constituting the alluvial fan onto which the industrial area of Ain Al Soukhna was constructed.

Regarding climate conditions, it is one of the main external driving forces that trigger various hydrological and geomorphic processes. Precipitation is the main and most influencing climatic parameter that initiates and controls the occurrence of flash flood events in drainage basins of all climatic zones. The collection of data about the frequency and magnitude of precipitations is a fundamental step to describe, understand, and model flash flood processes in the drainage basins of arid environments. The acquisition of such data is normally obtained from meteorological stations that are located in the neighborhood of the drainage basins. These stations record among other climatic parameters precipitations on a real-time basis. Although these data can provide valuable information on a particular region, it is difficult to use them for describing and modeling flash flood events that occur in drainage basins in arid lands for two significant constraints:

These stations provide point measurement data that corresponds to a limited geographic extension around the stations.

These stations are installed for helping navigation in seas and similar water bodies and are accordingly located along with coastal areas, as in the case of most stations in the Red Sea region. This makes the obtained climatic records not representative of the remotely located mountainous reaches, which receive the precipitations responsible for flash floods. 
The northwest Gulf of Suez catchment is located in an arid region, where the rates of evaporation exceed the rates of precipitations by many times. There are only two climatic stations in the catchment, namely: Jebel Attaqa and Adebah stations which are installed near the coastal area. As aforementioned, the poorly present precipitation data at few points cannot confidently be interpolated and/or extrapolated over the catchment area. The magnitude and intensity of the storms are often variable over the dry-land catchments within short distances. Consequently, an alternative source of the remotely sensed climatic data of the Terrain Rainfall Monitoring Mission (TRMM) (NASA, 2004) was considered.

Three hourly accumulated of rainfall in the last 13 years (2006-2020) has been acquired for the catchment from TRMM data (Figures. $4-7$ ) and analyzing these data showed the following:

- Annual rainfall patterns are almost similar to each other considering the spatial coverage and areas of high precipitation, magnitude, and intensity. The number of rainy days over the catchment area is larger than that of other catchments on the Red Sea coast.

- Annual rainfall is between $17 \mathrm{~mm}$ and $101 \mathrm{~mm}$, the highest precipitation amounts are found to be over areas of high topography in the south and north-west of the catchment. Coastal areas (where meteorological stations are located) receive the lowest amount of rainfall (Figure. 4).

- Most of the rainfall events occurred in winter months (November to March).

- Wadi El Abiad sub- catchment receives a modest amount of precipitation in the range of $25 \mathrm{~mm}$ to 65 mm (Figure. 5).

- The total accumulated rainfall in a month might be high. Nevertheless, if no significant accumulated rainfall occurs through any single day of that month, no flash flood should occur.

- For El Abiad sub-catchment, the maximum monthly precipitation occurred during February 2020 with a total amount of $60 \mathrm{~mm}$ that nearly equal the annual average rainfall over this sub-catchment (Figure. 6). $10 \mathrm{~mm}$ of precipitation was the maximum daily rainfall recorded during 10th February 2020 (Figure. $7)$.

From this analysis, it is possible to determine the months of the year which are the most prone to receive precipitations sufficient to trigger significant flash flood events. It has been found that the total annual rainfall over the north-western Gulf of Suez catchment is the highest recorded for any Red Sea catchment in Egypt. It should also be noted that the deviation in precipitation recorded in the watershed north-west Gulf of Suez is not very large, and the precipitation behavior on the studied catchment does not change much in terms of spatial coverage and intensity from one year to another. This indicates that odd storms of high magnitudes that are recorded over other catchments every decade or so are less likely to develop in the considered area, in which a rather persistent rainfall pattern prevails.

\section{MATERIALS AND METHODS}

\section{Digital Elevation Model (DEM)}

The digital elevation model (DEM) is remarkably important for extracting various topographic and hydrological parameters remotely (Wolock and Price, 1994; Zhang and Montgomery, 1994). It enabled extracting topographic features including "topography slopes (magnitudes and aspects), slope length and shape" besides, Hydrological parameters including "flow direction, flow accumulation, watershed delineation, flow networks, and flow length". Both parameters of flow accumulation and length were used to calculate the hypothetical hydrograph of the considered sub-catchment area (Singh, 1997).

From the DEM, the elevation of the north-west Gulf of Suez drainage basin ranges from 3 to 1274 meters above sea level, while the elevation of Wadi El Abiad sub-catchment ranges from 39 to $1274 \mathrm{~m}$. (Figure. 8).

\subsection{Flow direction and accumulation}

Hydrologically, the flow direction represents the D-8 algorithm of the direction of the flow within each pixel in relation to the eight neighborhood pixels. The flow direction has been extracted from the SRTM digital elevation model, which was a key input parameter to extract the flow length. Figure 9 shows the 
flow direction of Wadi El Abiad drainage basin, which are dimensionless values that range from 1 to 128 (see figure 10 - D-8 algorithm) (Jenson and Dominique 1988). The flow accumulation represents the total number of the upslope cells that flow to each down-slope cell that accumulates the flow to the main streams. Significant use of the flow accumulation is extracting the stream networks and sub-catchment areas. ArcGIS and the watershed function used in combination with the flow accumulation grid to compute the active upslope contributing area.

\subsection{Drainage networks and Sub-catchment delineation}

To delineate a drainage network or catchment area, the flow accumulation number thresholds have to be defined and selected by the user (Hutchinson 1989). This means that setting a threshold of 500 cells for the drainage network delineation will initiate the first fingertips of streams whenever the flow accumulation values exceed 500. These first fingertip streams are adjoined and connected in a downstream direction to form the drainage network map of the catchment. The threshold of 100 cells for the north-west Gulf of Suez catchment is appropriate to portray a drainage network with comparable spatial accuracy and density as those shown on the satellite images. On the contrary, the automatic catchment delineation requires selecting the flow accumulation of the most downstream of main channels (i.e. a point that will capture flow from whole the surface drainage network of its upstream). Therefore, the flow accumulation number at the outlet channels of El Abiad sub-catchment was defined and used as the minimum threshold required to delineate the sub-catchment watershed divides. The delineated sub-catchment of Wadi El Abiad has an area of 330 $\mathrm{km}^{2}$ (Figure. 11).

\subsection{Runoff velocities and hydrograph estimation}

For estimating the overland flow velocity, it is required to calculate the magnitude and direction of the flow. Considering the use of Manning equation (equation 1) (Mays 1999) we managed to estimate the magnitudes. The hydraulic radius was assumed to be as minimal of (0.05), the slope was obtained from the DEM of the area and Manning's coefficient value (n) was retrieved from standard tables (Arcement and Schneider, 1989 $\&$ El Bastawesy, 2006).

$V=R\left(\frac{2}{3}\right) * s\left(\frac{0.5}{n}\right)$

Where;

$\mathrm{V}=$ Velocity $\mathrm{m} / \mathrm{sec} ; \mathrm{R}=$ Hydraulic radius (i.e. $=$ depth); $\mathrm{S}=$ Slope percentage $\mathrm{n}=$ Manning coefficient

The flow direction network represents the direction of flow within each cell in the studied area to one of the eight adjacent cells (D-8 algorithm) (i.e, diagonal-red, or orthogonal-blue) (Figure. 10). Because the resolution of the DEM is known, it is possible to calculate the flow length within each cell which will be equal either to the grid cell length (L) in case of orthogonal or L[?]2 in case of diagonal (Figure. 10).

On this basis, the flow direction grid was reclassified to get the flow length within each cell. Once the flow velocities and flow lengths of each cell are estimated, the flow time of each cell is obtained by dividing the flow length by the velocity. The flow time network, which is the time required for the flow in each cell to reach the output, is estimated by using the flow length function in the Arc Info software, which uses the following convolution equation (Equation 2) (ESRI, 2000).

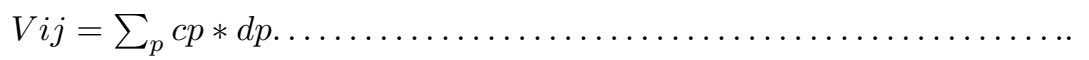

where,

$\mathrm{Vij}=$ the output result of the convolution for cell $(I, j) ; d=$ the slope distance between the centers of two adjacent cells along the minimum-cost path; $\mathrm{c}=$ the unit-distance cost value; $\mathrm{p}=$ the minimum-cost path.

Consequently, the grid representing the cell-travel time was regarded as the unit-distance cost value and was implemented in the calculation of a weighted flow-length. The time of flow grid represents the time in 
seconds required for the flow of each cell to reach the outlet. Finally, by dividing the time of flow grid by 3600 , then reclassifying the resulting map-enabled to express the estimated travel time in hourly intervals and then aggregated for the different zones in the time-area zones map (Figure. 12).

\section{RESULTS AND DISCUSSION}

\subsection{GIS spatially distributed unit hydrograph}

Each cell in this cumulative time grid has a value that indicates the time (in seconds) necessary for the runoff that is delivered to each cell for reaching the catchment outlet. Thus the catchment can be subdivided into different time-area zones (in hours) (Maidment, 1993). It is necessary to investigate the effect of the distribution of local rainfall and the consequent patterns of loss of transmission on the propagation of the runoff (Cooke et al., 1982; Beven, 2002). The calculated amount of runoff for the time area zones in Figure 12 using effective infiltration-surplus precipitation of $10 \mathrm{~mm}$ over the entire catchment is around 3,300,000 $\mathrm{m}^{3}$ (Figure. 13). The high permeability of wadi alluvium which is filled by gravels and chert boulders promotes a very high transmission loss rate from the surface runoff. The permeability was estimated to $50 \mathrm{~mm}$ per hour on average. The main active channels areas of the sub-catchment were measured from the satellite images, and it was found that the alluvial fan active area is nearly $13.2 \mathrm{sq} \mathrm{km}$. But the main channel feeding the alluvial fan has a very small active area $(2.6 \mathrm{sq} \mathrm{km})$ when compared with the alluvial fan. This means that the flows produced in the catchment different time zones will suffer huge transmission loss as soon as they enter the alluvial fan area. The flow generated onto Wadi El Abiad catchment 6 zones was linearly routed in a cascading way from zone 6 successively up to zone 1 (i.e. alluvial fan and dykes area).

Flows generated within the zone number 6 are subjected to transmission loss into the alluvium channel along with all the way downstream (i.e. from zones 6 to 1 ) until they reach the alluvial fan. But the flow generated within zone number 2, for example, will only suffer transmission loss into the alluvium of zones 1 and 2 . Accordingly, only the flow generated within the 5 th time zone (due to its large area) was sufficient to exceed the transmission loss into the downstream and to reach the outlet of the main wadi, but the surface runoff produced in remaining zones is completely consumed through transmission loss. We estimate that out of 834, produced from an excess rainfall event of (under a constant transmission loss rate of $50 \mathrm{~mm} /$ hour into the alluvium), only will reach the outlet. Therefore, the geological setting of this catchment (i.e. alluvium with large particle sizes) plays an important role in its flash floods, where most of the flow is lost through transmission loss.

\section{Runoff and sediment load validation}

The developed hydrograph of Wadi El Abiad suggests that small amounts of flow can be delivered to the outlet even under whole storm coverage with considerable intensity. As aforementioned, this is attributed to the geological setting and the large scale transmission loss. The preserved high water stands and their deposited layers of slack-fine sediments were used to validate the hydrological model output. It was found that only four events were able to deliver runoff and sediment to the dyke areas since construction in 2000. The maximum high stand observed was $80 \mathrm{~cm}$ in average behind the first dyke. Tape measurements along with GIS analysis suggest that the stored water volume of that event was nearly $21000 \mathrm{~m}^{3}$. The total thickness of clogged fine sediments reached $60 \mathrm{~cm}$ over an area extended upstream behind the dyke for a nearly $40 \mathrm{~m}$ on average (Figures. 16\& 17). It is worth to mention that the fine sediment load indicates that all the delivered flow behind the dykes were of low magnitude as the cobles and gravels spreading the alluvial fan were not triggered as a flow-bed load to reach the dyke. The slack deposits thickness is $15 \mathrm{~cm}$ and spread over a semi elongated area (probably scooped by bulldozers during construction) measuring 80 $\mathrm{m}$ in length and $11 \mathrm{~m}$ in width (Figures. 14\&15). The observed water high stand on that area was nearly $60 \mathrm{~cm}$ on average, and therefore, we can estimate that the maximum amount of water delivered to that dyke was $530 \mathrm{~m}^{3}$. It is evident that most of Wadi El Abiad flash floods are delivered to the other dykes and very little amounts of floods reach the dykes erected further downstream in the main wadi. Under the 
prevailing climatological and hydrological conditions, it is safe to say that complete silting up behind the dyke will not occur within the forthcoming 50 years. The silting up rate behind the other dyke in Wadi El Abiad catchment is much higher and it may be fully clogged within the next 50 years as nearly $15 \mathrm{~cm}$ of fine sediments are added up behind this dyke once every two years.

\section{Field measurements}

The field work and observations aims at validating the remote sensing results for flash floods and to assess the effectiveness of the precautions and remedial measures taken to protect the study area from flash flood hazards.

All the constructed protection dykes investigated were traced from satellite images and visited in the field to determine the following:

- The construction design of the dykes (i.e. building material, height, etc).

- Evidences of past flash flood records; this includes trash marks defined by traces of high stands of water on the walls of the dyke or surrounding channel banks. The traces are expressed by drifted shrubs, wood or mud drapes.

- The layers of slack mud deposits accumulated behind the dykes have been investigated by determining the number of successive mud layers in the dyke pool area, as it is directly related to the number of flow delivered to this area. Only one of the visited dykes displayed three trash marks expressing water high stands of different flood events (Figure. 18). These have been correlated with the thicknesses of the different sequences of slack deposits accumulated behind the dyke. The thicknesses being taken as an expression of the amounts of a suspended load of the flood and the height of the trash mark can be used to estimate the total volume of the delivered water. In Wadi El Abiad three main dykes were erected in the year 2000 to control flash flood. The other two consecutive dykes, to the east of the previously mentioned dyke, are controlling most of the flow delivered to the Wadi El Abiad alluvial fan. The dyke located upstream showed evidence for four flash floods, while the downstream dam displays no records of flash floods.

\section{Conclusion}

In conclusion, remote sensing, geological studies, DEM and fieldwork data were used in a GIS to determine a flash flood hydrograph for the Wadi El Abiad sub-catchment. The main channels on the braided alluvial fan of the sub-catchment are blocked by three dykes; one in the upstream of Wadi Naout and the other two are consecutive on the main channel to the east (at Wadi Umm Rasses). Flash flood flow loaded with fine sediments occur on average once every two years. Most of the flow is delivered to the channel are very little. The dyke upstream of Wadi Naout has a sufficient storage capacity, and it will not be fully clogged with sediments during the coming 50 years. On the other hand, the upstream dyke erected on the broader stream (at Wadi Umm Rasses) receives appreciable amounts of runoff and sediment loads. Field observations suggest that the complete silting up of the dyke pool area is imminent before the end of the coming 50 years , therefore the efficiency of these dykes are also being decreased due to deposition of sediment loads associated with the flash floods.

\section{DATA AVAILABILITY STATEMENT}

Data sharing are not applicable to this article as no datasets were generated or analysed during the current study.

\section{FUNDING}

The author(s) received no specific funding for this work.

\section{REFERENCES}


Arcement, G.J., \& Schneider, V.R. (1989). Guide for selecting Manning's roughness coefficients for natural channels and flood plains. United States Geological Survey Water-supply Paper 2339.Beven, K. (2002). Runoff generation in semi-arid areas. In Dryland Rivers, Hydrology and Geomorphology of Semi-arid Channels, Bull LJ, Kirkby MJ (eds). John Wiley and Sons: Chichester; 57-105.Broadman, J., Ligneau, L., De Roo, A.P.J., \& Vandaele, K. (1994). Flooding of property by runoff from agricultural land in northwestern Europe. Geomorphology 10, 183-196. https://doi.org/10.1016/0169-555X(94)90016-7CONCO, C. (1987) .Geological map of Egypt, scale 1: 500,000. Geological Survey and Egyptian General Petroleum Corporation, Cairo.Cooke, R.U., Brunsden, D., \& Doornkamp, J.C. (1982). Urban Geomorphology in Drylands. Oxford University Press: Oxford. https://doi.org/10.1002/esp.3290080617Darwish, M.H., Megahed, H.A., \& Farrag, A. H.A. (2020). Geo-Environmental Changes and Their Impact on the Development of the Limestone Plateau, West of Assiut, Egypt. Journal of the Indian Society of Remote Sensing 48, 1705-1727. https://doi.org/10.1007/s12524-020-01158-9De Roo, A.P.J. (1999). Modelling runoff and sediment transport in catchments using GIS. In: Gurnell, A.M., Montgomery, D.R. (Eds.), Advances in Hydrological Process, Hydrological Applications of GIS. John Wiley and Sons, Chichester, England.El Bastawesy, M., White, K., \& Nasr, A. (2009). Integration of remote sensing and GIS for modelling flash floods in Wadi Hudain catchment, Egypt. Hydrological Processes Journal. https://doi.org/10.1002/hyp.7259El Bastawesy, M. (2006). Influence of DEM source and resolution on the hydrographical simulation of Wadi Keed catchment, Southern Sinia, Egypt. The Egyptian Journal of Remote Sensing and Space Science 9: 68-79.El Bastawesy, M. (2005). Development of a GIS-based hydrological model for the hyper-arid catchment of Wadi Haymour. Unpublished $\mathrm{PhD}$ thesis, University of Reading, UK.ESRI (Environment System Research Institute). (2000). GIS Manual, ESRI Ltd., California, USA, p. 335.Farrag, A. E.A., Megahed, H. A., \& Darwish, M. H. (2019).Remote sensing, GIS and chemical analysis for assessment of environmental impacts on rising of groundwater around Kima Company, Aswan, Egypt. Bulletin of the National Research Centre, 43(1), 14.https://doi.org/10.1186/s42269-019-0056-3Gheith, H., \& Sultan, M. (2002). Construction of a hydrologic model for the estimating wadi runoff and groundwater recharge in the Eastern Desert, Egypt. Journal of Hydrology 263: 36-55. https://doi.org/10.1016/S00221694 (02)00027-6Hutchinson, M. F. (1989). A new procedure for gridding elevation and stream line data with automatic removal of spurious pits. Journal of Hydrology 106: 211-232. https://doi.org/10.1016/00221694(89)90073-5Jenson, S.K., \& Dominique, J.O. (1988). Extracting topographic structure from digital elevation data for geographic information system analysis. Photogrammetric Engineering and Remote Sensing 54:1593-1600.Maidment, D.R. (1993). Hydro GIS 93: application of geographical information system in hydrology and water resources. Proceeding of the Vienna Conference. IAHS Publication No. 211.Mays, L.W. (1999). Hydraulic Design Handbook, McGraw-Hill Professional, 1st edition, 1024 pp.McMahon, T.A. (1979). Hydrological characteristics of arid zones. In The Hydrology of Areas of Low Precipitation, Proceedings of Canberra Symposium. IAHS Publication 128; 105-123.Megahed, H.A. (2020). GIS-based assessment of groundwater quality and suitability for drinking and irrigation purposes in the outlet and central parts of Wadi El-Assiuti, Assiut Governorate, Egypt. Bull Natl Res Cent 44, 187. https://doi.org/10.1186/s42269-020-00428-3Megahed, H. A. (2020). Hydrological and archaeological studies to detect the deterioration of Edfu temple in Upper Egypt due to environmental changes during the last five decades. SN Appl. Sci. 2, 1952. https://doi.org/10.1007/s42452-020-03560xMegahed, H.A., \& El Bastawesy, M.A. (2020).Hydrological problems of flash floods and the encroachment of wastewater affecting the urban areas in Greater Cairo, Egypt, using remote sensing and GIS techniques. Bull Natl Res Cent 44, 188. https://doi.org/10.1186/s42269-020-00442-5Megahed, H. A., \& Farrag, A.E.A. (2019). Groundwater potentiality and evaluation in the Egyptian Nile Valley: case study from Assiut Governorate using hydrochemical, bacteriological approach, and GIS techniques. Bulletin of the National Research Centre, 43(1), 48.https://doi.org/10.1186/s42269-019-0091-0NASA (National Aeronautics and Space Administration). (2004). Global Precipitation Mission [Online]. Available at <http:// gpm.gsfc.nasa.gov/index.html> (accessed 29.11.2004).Walsh, S.J., Butler, D.R., \& Malanson, G.P. (1998). An overview of scale, pattern, process relationships in geomorphology: a remote sensing and GIS perspective. Geomorphology 21, 183-205. https://doi.org/10.1016/S0169-555X 
(97)00057-3White, K. (1995). Field techniques for estimating downstream changes in discharge of gravelbedded ephemeral streams: a case study in southern Tunisia. Journal of Arid Environments 30: 283-294. https://doi.org/10.1016/S0140-1963 (05)80003-5Wilson, J.P., \& Gallant, J.C. (2000). Digital Terrain Analysis: Principals and Applications. In: Wilson, John P., Gallant, John C. (Eds.), John Wiley and Sons, Inc., ISBN 0-471-32188-5.Wolock, D.M., \& Price, C.V. (1994). Effects of digital elevation map scale and data resolution on a topographically based watershed model. Water Resources Research 30: 3041-3052. https://doi.org/10.1029/94WR01971Zhang, W., \& Montgomery, D.R. (1994). Digital elevation model grid size, landscape representation, and hydrological simulations. Water Resources Research 30: 1019-1028. https://doi.org/10.1029/93WR03553FIGURE LEGENDS

Fig. 1 Landsat satellite image for the north-west Gulf of Suez catchment, showing Wadi El Abiad subcatchment delineated by red line.

Fig. 2 Location of some constructed dykes in Wadi Ghuwaba area for flash flood protection.

Fig. 3 Geological map of the study area, modified after CONOCO 1987.

Fig. 4 Average annual rainfall for the northwest Gulf of Suez catchment from 1st of Jan 2006 to 31 Dec 2020 was obtained from TRMM data (NASA, 2004).

Fig. 5 Average precipitation over Wadi El Abiad sub-catchment.

Fig. 6 Maximum monthly rainfall record (Feb 2020) over the northwest Gulf of Suez catchment.

Fig. 7 Maximum daily rainfall (10th of Feb 2020) over the northwest Gulf of Suez catchment.

Fig. 8 DEM for the northwest Gulf of Suez catchment, Wadi El Abiad sub-catchment is outlined by red line.

Fig. 9 Flow direction map for Wadi El Abiad sub-catchment.

Fig. 10 Schematic diagram shows the D-8 algorithm of flow direction.

Fig. 11 The delineated drainage networks for Wadi El Abiad.

Fig. 12 The estimated hourly time -area zones of Wadi El Abiad.

Fig. 13 A hypothetical runoff hydrograph when the estimated time area zones receive a uniform effective precipitation of $10 \mathrm{~mm}$ per hour at once.

Fig. 14 Field view of the eastern part of Wadi Naout, note the small area being filled with silt and clay behind the dyke. The red square refers to the site of the picture of Figure. 15.

Fig. 15 Average thicknesses of the two delivered suspended load behind the dyke at Wadi Naout during the period from 2006 to 2020 . The older and thinner load is under the tape and the last one is thicker, displaying more conspicuous mud cracks.

Fig. 16 Wadi Umm Rassis dyke trapping conspicuous mud layers (surface to the right of the picture). The red square refers to the site of the picture in Fig. 17.

Fig. 17 Measurement of thickness of flash flood suspended load behind Umm Rassis dyke.

Fig. 18 Trash marks as evidence of three floods on a dyke erected in a main stream. This stream is subjected to severe flash floods events.

\section{Hosted file}

Figures.pdf available at https://authorea.com/users/397785/articles/510569-hydrologicalassessment-of-flash-flood-hazards-and-the-constructed-mitigation-measures-in-wadisaffecting-ain-al-soukhna-northwest-gulf-of-suez-egypt 